Southern Methodist University

SMU Scholar

\title{
A Rose by Any Other Name: How the United States Charges Its Service Members for Violating the Laws of War
}

Chris Jenks

Southern Methodist University, Dedman School of Law

\section{Recommended Citation}

Chris Jenks, A Rose by Any Other Name: How the United States Charges Its Service Members for Violating the Laws of War in MILITARY JUSTICE IN THE MODERN AGE (Cambridge, Cambridge University Press, 2016)

This document is brought to you for free and open access by the Faculty Scholarship at SMU Scholar. It has been accepted for inclusion in Faculty Journal Articles and Book Chapters by an authorized administrator of SMU Scholar. For more information, please visit http://digitalrepository.smu.edu. 


\title{
A rose by any other name: how the United States charges its service members for violating the laws of war
}

\author{
CHRIS JENKS
}

\section{Introduction}

In the early morning of 11 March 2012, a US service-member, Staff Sergeant Robert Bales, slipped undetected from Village Stability Platform Belambai (VSP) about 30 kilometres from Kandahar, Afghanistan. Bales was one of approximately forty US military personnel deployed to VSP Belambai. Their mission was 'to assist the Afghan government in maintaining security, reconstructing the country, training the national police and army, and providing a lawful environment for free and fair elections. ${ }^{1}$ Sergeant Bales, however, was on a very different mission.

Bales, alone and on foot, hiked to two separate Afghan villages where he murdered sixteen women and children, attempted to murder six more, and assaulted others. ${ }^{2}$ The victims ranged in age from small children to an elderly grandmother. Bales murdered eleven members of one family, shooting most of them in front of one another, stomped to death at least one victim and set ten victims' bodies on fire. The US Army apprehended Bales as he attempted to return to VSB Belambai. The Army transferred Bales to the United States and military confinement and prosecuted him under the US military's criminal law and procedure, the Uniform Code of Military Justice (UCMJ). At an Army court martial held in June 2013 in the United States, Bales pleaded guilty to sixteen counts of premeditated murder, six counts of attempted murder and six counts of aggravated

Borrowing from Shakespeare's, Romeo and Juliet: 'What's in a name? That which we call a rose. By any other name would smell as sweet.'

${ }^{1}$ United States Mission to NATO, U.S. Policy toward Afghanistan \& Pakistan: A Dossier (2014) United States Mission to NATO http://nato.usmission.gov/afghanistan.html.

2 United States $\mathrm{v}$ Robert Bales, Charge Sheet (23 March 2012) (redacted). A redacted version of the charge sheet is available at http://i2.cdn.turner.com/cnn/2012/images/03/23/bales .charge.pdf. 
assault inflicting grievous bodily injury. A military panel, or jury, sentenced Bales to be dishonourably discharged and to be confined for the duration of his natural life without the possibility of parole.

In so doing, the US Army continued its long-standing policy and practice of asserting jurisdiction over its service members who commit crimes during armed conflict and charging them with enumerated offences of the UCMJ rather than violations of the laws of war, or war crimes. Yet, while not prosecuting its own service members with such crimes, the United States continues to conduct military commissions at Guantanamo Bay, Cuba and to prosecute members of al Qaeda and the Taliban for just such offences, that is, violations of the laws of war.

This chapter examines the US practice of not charging its service members with war crimes. The chapter briefly explains how the United States asserts criminal jurisdiction over its service members before turning to how the US military reports violations of the laws of war. It then sets out the US methodology for charging such violations as applied to its service members, and compares this methodology to that applied to those tried by military commissions. The chapter then discusses the varied meanings of the term 'war crimes' and the way in which the 1949 Geneva Conventions can provide a benchmark against which the elements of offences, and their punishments, can be compared. While the US practice fares adequately in this comparison, the argument for a pragmatic approach to charging over the expressive value of a war crime charge is rendered untenable as a result of the disparate manner in which the United States charges detainees when compared to its own service members.

\section{US practice \\ A History of the UCMJ}

The UCMJ resulted from the US Congress' desire, following World War II, to establish a 'a code that would apply to all branches of the military and create greater uniformity in the substantive and procedural law governing the administration of military justice.' ${ }^{3}$ While the UCMJ dates from 1951, its origins are in and with the founding of the United States during the American Revolutionary War with England. In June 1775, the fledging (and rebellious) Second Continental Congress enacted the Articles of War, which, somewhat ironically were 'generally a copy of

3 Mynda G. Ohman, 'Integrating Title 18 War Crimes into Title 10: A Proposal to Amend the Uniform Code of Military Justice' (2005) 57 Air Force Law Review, p. 1 at 4. 
the then-existing code governing England's "ministerial army"'. Following the Revolutionary War, the US Constitution granted the US Congress the power '(1) to make Rules for the Government and Regulation of land and naval Forces'; and '(2) to define and punish ... offenses against the Law of Nations'. ${ }^{5}$ Thus, beginning with the 1806 revisions to the Articles of War, US 'military personnel were subject to a code that required them to obey certain laws and customs of war or face trial by court-martial or military tribunal'. ${ }^{6}$ In the century that followed, the US Congress updated the Articles of War in 1874 and $1916 .{ }^{7}$ The articles were again amended in 1920, with lessons learned from World War I, and in 1949 following World II. ${ }^{8}$ The 1951 UCMJ replaced the Articles of War and established 'a single codified system of military law, separate from the criminal justice systems of the various states and of the Article III [federal] courts'. ${ }^{9}$ The features of the UCMJ have been described as follows:

The UCMJ permanently transformed the nature of military law. The UCMJ was more than a structural change to ensure uniformity across all branches of service. It added articles, defined new crimes, and established rules designed to protect the substantive and procedural rights of military personnel. New provisions designed to ensure a fair trial included the right against self-incrimination; equal process for the defense and prosecution to obtain witnesses and depositions; the prohibition on receiving guilty pleas in capital cases; the requirement that both prosecution and defense counsel be legally trained; the right for an enlisted accused to be tried by a panel [military jury] that included enlisted members; the requirement that the law officer (now the military judge) instruct the panel members on the record regarding the elements of the offense, presumption of innocence, and burden of proof; the provision mandating that voting on findings and sentencing be conducted by secret ballot; and an automatic review of the trial record. ${ }^{10}$

One of the advantages of the UCMJ is its broad jurisdictional scope.

${ }^{4}$ Judge Advocate General's Corps, US Army, The Army Lawyer: A History of the Judge Advocate General's Corps, 1775-1975 (Washington, DC, Government Printing Office, 1975), p. 7. The following month the Congress elected William Tudor as the first Judge Advocate General of the Army.

${ }^{5}$ United States Constitution art. $1 \$ 8$ cl. 14. See also Tara Lee, 'American Courts-Martial for Enemy War Crimes' (2003) 33 University of Baltimore Law Review, p. 49 at 52-53.

${ }^{6}$ Eric Talbot Jensen and James J Teixeira Jr, 'Prosecuting Members of the U.S. Military for Wartime Environmental Crimes' (2005) 17 Georgetown International Environmental Law Review, p. 651 at 658.

${ }^{7}$ Ohman, above n. 3, at $4 .{ }^{8}$ Ibid. ${ }^{9}$ Lee, above n. 5, at 52-53.

${ }^{10}$ Ohman, above n. 3, at 9-10. 
The UCMJ applies to all [US] service members regardless of whether the offense can be tied to military discipline and effectiveness. The UCMJ is applicable both in the United States and in foreign countries. Because the UCMJ applies worldwide, a court-martial convened under the UCMJ may be held anywhere in the world. This flexibility allows for the prosecution to take place near the situs of the crime, presumably near the location of any relevant witnesses. This makes the prosecution of a crime that occurs during the conduct of military operations, such as in Iraq [or Afghanistan], easier than it would be if the case had to be heard in a Federal District Court or before an international body convened at the Hague or some other site distant from the court's location. ${ }^{11}$

For the UCMJ to have personal jurisdiction over US service-members regardless of where in the world the service-member is or whether they were on or off duty is one of the strengths of the system. But the manner in which the system charges US service members for crimes blunts the efficacy, either real or perceived, of the UCMJ as an accountability mechanism.

\section{$B$ Charging violations of the laws of war}

As one US Army lawyer noted in a primer for the practitioner of charging war crimes, '[ $\mathrm{t}]$ he first step in analyzing how to charge the service member is to look for any offenses specifically enumerated in the UCMJ Articles 80 through 132. ${ }^{12}$ These articles address a wide range

11 Jensen and Teixeira, above n. 6, at 658. Although one of the advantages of the UCMJ is the ability to hold courts martial in a combat theatre such as Iraq or Afghanistan, it is noteworthy that often the US military does not choose this course of action. As discussed in the introduction, Staff Sergeant Bales committed his crimes in Afghanistan and against Afghan civilians, but Bales' court martial was held in the United States.

12 Martin N. Watt, 'Charging War Crimes: A Primer for the Practitioner' (February 2006) Army Lawyer, p. 2. As Watt explains, '[ $t$ ] he [service lawyer prosecutor] should begin with this analysis due to the preemption doctrine'. The preemption doctrine 'prohibits application of Article 134 to conduct covered in Articles 80 through 132'. Id. Article 134 is for misconduct not addressed in the enumerated punitive section of the UCMJ. Article 134 of the UCMJ, among other things, allows for the incorporation of federal offences as a military charge. But under the preemption doctrine, a prosecutor may not incorporate a federal charge to address conduct an enumerated article of the UCMJ covers. For example, Article 118 of the UCMJ criminalises murder. The US Code, in Title $18 \S$ 1111 also criminalises murder. Therefore a military prosecutor would need to charge the murder offence under Article 118; he or she could not incorporate the federal murder offence through Article 134. However, unlike the UCMJ, the US Code specifically criminalises war crimes as such, in Title $18 \S 2441$. This raises the question of whether a military prosecutor could incorporate the federal statute under Article 134 and thus charge a US service member with war crimes. The answer where the underlying conduct 
of criminal conduct, and include both completed and inchoate offences. The crimes listed in the UCMJ include common offences such as larceny, assault, rape and murder and arcane offences, such as abusing a public animal and jumping from a vessel to the water. There is no enumerated offence for violating the laws of war. Yet the UCMJ itself acknowledges that ' $[\mathrm{t}$ ] $\mathrm{o}$ the extent permitted by the [US] Constitution, courts-martial may try any offense under the code, and in the case of a general courtsmartial, the law of war. ${ }^{13}$

In explaining how to allege offences, the current US Manual for CourtMartial states that '[a] charge states the article of the code, law of war, or local penal law of an occupied territory which the accused is alleged to have violated'. ${ }^{14}$ Not only does this indicate the possibility of a law of war charge, the accompanying discussion details that '[i]n the case of a person subject to trial by general court-martial for violations of the law of war, the charge should be: "Violation of the Law of War". ${ }^{15}$ But that discussion concludes with the guidance that '[o]rdinarily persons subject to the code [a category which includes US service members] should be charged with a specific violation of the code rather than a violation of the law of war' ${ }^{16}$ Likewise, the Department of the Army's field manual, The Law of Land Warfare, in a section entitled Persons Charged with War Crimes, states that 'The United States normally punishes war crimes as such only if they are committed by enemy nationals or by persons serving the interests of the enemy State. Violations of the law of war committed by persons subject to the military law of the United States will usually

is reflected in a punitive article is unclear. For example, if a military prosecutor incorporated the federal war crimes statute and charged a grave breach of the Geneva Conventions, the unlawful killing of a protected person, the defence would challenge such a charge under the preemption doctrine, arguing that Article 118 of the UCMJ already addresses unlawful killing. But to the extent the underlying conduct is not reflected in a punitive article of the UCMJ, charging the conduct as a war crime through Article 134 and the federal statute appears a possibility. The challenge is to identify acts which constitute a grave breach of the Geneva Conventions or violate Common Article 3 and which are not already reflected in a punitive article of the UCMJ.

13 Manual for Courts-Martial, Rules for Courts-Martial r. 202 (2012). See also Uniform Code of Military Justice, 10 USC $\$ 818$ art. 18 (2010).

14 Manual for Courts-Martial, Rules for Courts-Martial r. 307(c)(2) (2012).

15 Ibid., Discussion (D).

16 Ibid. The analysis of that rule, also contained in the Manual for Courts-Martial, adds little clarity. The appendix to the 1969 Manual for Courts-Martial merely states that '[i]n the case of a person subject to trial by general court-martial by the law of war ..., the Charge should be: "Violation of the Law of War"': Manual for Courts-Martial (1969) Appendix 6a at [12]. That same manual lists as a source of military jurisdiction, international law, which it states includes the laws of war. 
constitute violations of the Uniform Code of Military Justice and, if so, will be prosecuted under that law. ${ }^{17}$

That guidance, while not styled as an absolute requirement, has proved to be one in US practice. For example, the US charged Lieutenant Calley with violating Article 118, Murder, of the UCMJ, for his role in the Mei Lai massacre during the Vietnam War. There is considerable similarity between the charges against Calley and Bales. Calley was charged as follows:

In that First Lieutenant William L. Calley, Jr ... did, at My Lai 4, Quang Ngai Province, Republic of South Viet-Nam, on or about 16 March 1968, with premeditation, murder an unknown number, not less than seventy, Oriental human beings, males and females of various ages, whose names are unknown, occupants of the village of My Lai 4, by means of shooting them with a rifle. ${ }^{18}$

Bales was charged as follows: '[i]n that Staff Sergeant (E-6) Robert Bales, U.S. Army, did, at or near Belambay, Afghanistan, on or about 11 March 2012, with premeditation, murder a female of apparent Afghan descent known as [redacted] by means of shooting her with a firearm' ${ }^{19}$

The historian for the US Army Judge Advocate Generals' Corps claims that the United States has never charged a US service member with a law of war violation as such. ${ }^{20}$ But one commentator, Professor (and former Army lawyer) Jordan Paust, claims that the United States charged a service member during the Vietnam War with 'cutting off an ear from the body of an unknown dead Viet Cong soldier, which conduct was of a nature to bring discredit upon the Armed Forces of the United States as a violation of the Law of War. ${ }^{21}$

The legislative intent behind Rule for Court Martial 307, or the commentary, provides no clarification. Noted Army legal scholars, and

17 Department of the Army Field Manual FM 27-10 The Law of Land Warfare (July 1956) at [507].

18 United States v. First Lieutenant William L Calley, Jr, Charge Sheet (5 September 1969) Specification 1. Similar action was taken with respect to Calley's Company Commander, Captain Medina. 'In keeping with United States policy, Captain Medina was not charged with violations of the law of war, but rather, was charged with violations of the UCMJ.' Michael L. Smidt, 'Yamashita, Medina, and Beyond: Command Responsibility in Contemporary Military Operations' (2000) 164 Military Law Review, p. 155, at 194.

19 United States v. Robert Bales, Charge Sheet (23 March 2012) (redacted) Charge I, Specification 1.

20 Email from Fred Borch to author, 6 November 2012.

${ }^{21}$ Jordan Paust, 'My Lai and Vietnam: Norms, Myths and Leader Responsibility' (1972) 57 Military Law Review, p. 99, at 118 (referring to United States v. Passantino, Hq. 1st Inf. Div. Special Court-Martial Or-der No. 11, 11 February 1968). 
military justice practitioners, claim that, as stated in the Manual for Courts-Martial, the United States may court-martial a US service member for a violation of the law of war. ${ }^{22}$ The US Congress has also failed to provide an answer, although it briefly discussed the issue in 1996. During the debate on the War Crimes Act, members of Congress discussed the potential for US service members to be court-martialled for violating the law of war and determined that it 'was not a viable option'. ${ }^{23}$

\section{Commissions}

The US military's internal practice stands in stark contrast to that of the military commissions, the stated purpose of which is to 'try alien unprivileged enemy belligerents for violations of the law of war. ${ }^{24}$ The Military Commissions Act of 2009 lists a host of law of war violations, including murder of a protected person, attacking civilian objects and property, pillaging and the denial of quarter. ${ }^{25}$ In its zeal to charge law of war offences in the commissions, the United States added the qualifier in violation of the law of war' to other charges, such as murder and destruction of property, when no such crimes exist, at least in the traditional, international, conception of the law. ${ }^{26}$ But before the US approach can be evaluated and discussed, clarifications to the terminology are warranted.

\section{War crimes}

A common misconception is that any violation of the Geneva Conventions is a war crime. ${ }^{27}$ First, the Conventions do not utilise the term war crimes. Instead, each of the four Conventions details violations

22 Jan E. Aldykiewicz and Geoffrey S. Corn, 'Authority to Court-Martial Non-U.S. Military Personnel for Serious Violations of International Humanitarian Law Committed During Internal Armed Conflicts' (2001) 167 Military Law Review, 74, at 76.

${ }^{23}$ Ibid. ${ }^{24}$ Military Commissions Act of 2009, 10 USC $\$ 948$ b(a) (2009).

${ }^{25}$ Ibid., $\$ 950 t(1)$. Given the US’ opposition to the ICC, the similarities between criminal offences under the Rome Statute and the Military Commissions Act of 2009 are interesting. That a US citizen could not be subject to prosecution for such offences by military commission reinforces a common US stereotype: the United States holds itself to a lower standard than that it claims others should meet under international law.

${ }^{26}$ See John Dehn, 'The Hamdan Case and the Application of a Municipal Offence: The Common Law Origins of "Murder in Violation of the Law of War"' (2009) 7(1) Journal of International Criminal Justice, p. 63.

27 The US Army's own field manual on the Law of Land Warfare is, at least in part, to blame. It states, that " $\mathrm{t}$ ] he term "war crime" is the technical expression for a violation of the law of war by any person or persons, military or civilian. Every violation of the law of war is a 
that constitute a 'grave breach' of the particular Convention. For those violations, States Parties have agreed to enact legislation to provide 'effective penal sanction'. ${ }^{28}$ The Conventions refer to lesser violations as 'other than grave breaches', for which States Parties agree to 'take measures necessary for the suppression' of such acts. ${ }^{29}$

\section{A International law}

In its study of international humanitarian law, the International Committee of the Red Cross (ICRC) attempted to identify the customary international law principles of international humanitarian law. Rule 156 of the study states that 'serious violations of international humanitarian law constitute war crimes'. ${ }^{30}$ In response, the legal advisers to the United States Departments of Defense and State wrote a letter to the ICRC claiming that the term war crimes is an amorphous term used in different contexts to mean different things'. ${ }^{31}$ The United States stated that:

The national legislation cited in the commentary to Rule 157 employs a variety of definitions of 'war crimes', only a few of which closely parallel the definition apparently employed by the Study, and none that matches it exactly. Much of the legislation cited does not precisely define 'war crimes' ... Although the military manuals of Croatia, Hungary, and Switzerland, among others, appear to define 'war crimes' as 'grave breaches', the lack of specificity leaves the intended meaning ambiguous. Even among the few States that employ a definition of 'war crimes' similar to that in Rule 156 , no State definition mirrors the Study's definition precisely. ${ }^{32}$

Part of the difficulty stems from what constitutes 'serious'. This is then compounded by the definition of international humanitarian law. US

war crime': Department of the Army Field Manual 27-10 The Law of Land Warfare (1956) at [499].

28 Geneva Convention Relative to the Treatment of Prisoners of War, 12 August 1949, in force 21 October 1950, 75 UNTS 135 art. 129 (Geneva Convention III).

29 Ibid.

30 Jean-Marie Henckaerts, 'Study on Customary International Humanitarian Law: A Contribution to the Understanding and Respect for the Rule of Law in Armed Conflict' (2005) 87(857) International Review of the Red Cross: Customary Law, p. 175 at 211, r. 156 ('ICRC Study').

31 John B. Bellinger III and William J. Haynes II, 'A US Government Response to the International Committee of the Red Cross Study Customary International Humanitarian Law' (2007) 89(866) International Review of the Red Cross, p. 443, at 467. Rule 157 provides that 'States have the right to vest universal jurisdiction in their national courts over war crimes.'

32 Ibid. 
federal law and the Rome Statute of the International Criminal Court provide similar definitions which serve as a starting point for a comparison to their counterpart under the UCMJ.

US federal law provides that ' $[w]$ hoever, whether inside or outside the United States, commits a war crime... shall be fined under this title or imprisoned for life or any term of years, or both, and if death results to the victim, shall also be subject to the penalty of death' ${ }^{33}$ Pursuant to this approach, a war crime includes grave breaches of any of the 1949 Geneva Conventions, certain articles from the 1907 Hague Convention IV, grave breaches of article 3 common to each of the 1949 Geneva Conventions and certain violations of Protocol II of the Convention on Certain Conventional Weapons, the Protocol on Prohibitions or Restrictions on the Use of Mines, Booby-Traps and Other Devices.

The Rome Statute defines war crimes as grave breaches of the 1949 Geneva Conventions, 'serious violations of the laws and customs' applicable to international and other than international armed conflict, and serious violations of article 3 common to each of the 1949 Geneva Conventions. ${ }^{34}$

\section{Elements comparison}

How then do the elements (and punishments) of Rome Statute war crimes compare to an analogous charge under the UCMJ? This section compares the following offences: wilful killing, committing outrages

33 War Crimes Act of 1996, 18 USC $\$ 2441$ (1996). Under the federal law, the term 'war crime' means any conduct:

(1) defined as a grave breach in any of the international conventions signed at Geneva 12 August 1949, or any protocol to such convention to which the United States is a party;

(2) prohibited by Article 23, 25, 27, or 28 of the Annex to the Hague Convention IV, Respecting the Laws and Customs of War on Land, signed 18 October 1907;

(3) which constitutes a grave breach of common Article 3 (as defined in subsection (d)) when committed in the context of and in association with an armed conflict not of an international character; or

(4) of a person who, in relation to an armed conflict and contrary to the provisions of the Protocol on Prohibitions or Restrictions on the Use of Mines, Booby-Traps and Other Devices as amended at Geneva on 3 May 1996 (Protocol II as amended on 3 May 1996), when the United States is a party to such Protocol, willfully kills or causes serious injury to civilians.

${ }^{34}$ Rome Statute of the International Criminal Court, 17 July 1998, in force 1 July 2002, 2187 UNTS 90 art. 8 (Rome Statute). 
against personal dignity, wilfully causing great suffering or serious injury, and extensive destruction of property.

The elements for each war crime under the Rome Statute include that the conduct took place 'in the context of and was associated with' an armed conflict and that the accused was aware of that conflict. Yet the introduction to the elements explains that:

There is no requirement for a legal evaluation by the perpetrator as to the existence of an armed conflict or its character as international or noninternational;

In that context there is no requirement for awareness by the perpetrator of the facts that established the character of the conflict as international or non-international;

There is only a requirement for the awareness of the factual circumstances that established the existence of an armed conflict that is implicit in the terms 'took place in the context of and was associated with'. ${ }^{35}$

\section{A Wilful killing}

Article 8(2)(a)(i) of the Rome Statute provides the following elements for the crime of wilful killing to be committed in an international armed conflict:

1. The perpetrator killed one or more persons.

2. Such person or persons were protected under one or more of the Geneva Conventions of 1949.

3. The perpetrator was aware of the factual circumstances that established that protected status.

4. The conduct took place in the context of and was associated with an international armed conflict.

5. The perpetrator was aware of factual circumstances that established the existence of an armed conflict. ${ }^{36}$

Article 118 of the UCMJ provides as follows:

1. That a certain named or described person is dead.

2. That the death resulted from the act or omission of the accused.

3. That the killing was unlawful.

${ }^{35}$ International Criminal Court, Elements of Crimes, Doc No. ICC-ASP/1/3 (part II-B) (adopted 9 September 2002) art. 8 (Elements of Crimes).

${ }^{36}$ Ibid., art. 8(2)(a)(i). 
4. That, at the time of the killing, the accused had a premeditated design to kill. ${ }^{37}$

The maximum punishment under the UCMJ is death. There is a mandatory minimum of imprisonment for life with eligibility for parole. For the ICC crimes, the maximum punishment for war crimes is 'life imprisonment when justified by the extreme gravity of the crime and the individual circumstances of the convicted person'. ${ }^{38}$

Facially, the differences between the UCMJ and the ICC Statute are a higher mens rea in case of the UCMJ (premeditation) and the fact that wilful killing under the ICC requires proving both the protected status of the victim and the underlying existence of an armed conflict. Qualitatively wilful killing is a more circumspect offence, proscribing a rule not against any wilful killing, but the wilful killing of a certain class of victims - protected persons.

Could Staff Sergeant Bales be charged with wilful killing? Even with the expansion of protected person status to include ethnicity and not just nationality, ${ }^{39}$ the alleged victims were not protected persons for the purposes of the Geneva Conventions. They were Afghan nationals, allegedly killed in Afghanistan by a member of the US military when the US military was neither fighting against nor occupying Afghanistan, but instead aiding the government of Afghanistan in its counter-insurgency efforts. Thus, while the offence of wilful killing is uniquely tailored to armed conflict, it proves less useful in certain conflict based settings than the more general murder charge under the UCMJ.

\section{B Maltreatment of persons}

Article 8(2)(c)(ii) of the Elements of Crimes outlines the elements of the crime 'outrages upon personal dignity' as follows:

1. The perpetrator humiliated, degraded or otherwise violated the dignity of one or more persons.

2. The severity of the humiliation, degradation or other violation was of such degree as to be generally recognized as an outrage upon personal dignity.

37 Uniform Code of Military Justice, 10 USC $\$ 918$ art. 118 (2010).

38 Rome Statute, above n. 34, art. 77 (1).

39 Prosecutor v. Tihomir Blaskic (International Criminal Tribunal for the former Yugoslavia, Appeals Chamber, Case No IT-95-14-T, 3 March 2000) at 3. 
3. The conduct took place in the context of and was associated with an international armed conflict.

4. The perpetrator was aware of factual circumstances that established the existence of an armed conflict.

In article 93 of the UCMJ 'cruelty and maltreatment' is defined as:

1. That a certain person was subject to the orders of the accused.

2. That the accused was cruel toward, or oppressed, or maltreated that person.

In the UCMJ the maximum punishment is dishonourable discharge, forfeiture of all pay and allowances, and confinement for one year. Once more the Rome Statute provides for a maximum term of thirty years or life in particularly grave circumstances. Attention is immediately drawn to the brevity of the UCMJ charge (it contains only two elements) as well as the disparity between possible punishments: one year compared to thirty years. Arguably the UCMJ charge is not analogous to the ICC offence, or certainly not a complete equivalent. The UCMJ charge requires that the victim be subject to the orders of the accused. While being subject to orders is broadly defined, it is nonetheless a significant limitation on the application of the charge. Finally, under the UCMJ offence the victim must be alive. By comparison, an outrage against personal dignity better lends itself to the misconduct that occurs during armed conflict, particularly towards corpses. ${ }^{40}$ For outrages against personal dignity, the Elements of Crimes provides that "persons" can include dead persons. It is understood that the victim need not personally be aware of the existence of the humiliation or degradation or other violation. This element takes into account relevant aspects of the cultural background of the victim. $^{41}$

${ }^{40}$ For example, some of the actions US service members have taken in recent years in Afghanistan, including urinating on, or burning, corpses; videotaping and photographing themselves with corpses and cutting off body parts as trophies could fall within this crime. In Iraq, the Abu Ghraib abuses could constitute such violations. As the detainees were subject to the orders of the US military guards cruelty and maltreatment could (and did) apply. In such situations, the question becomes whether a maximum sentence of one year confinement is adequate.

${ }^{41}$ Elements of Crimes, above n. 35, art. 8(2)(c)(ii). 


\section{Wilfully causing great suffering or serious injury}

Article $8(2)(a)($ iii) provides that the crime of wilfully causing great suffering or serious injury to body or health occurs when:

1. The perpetrator caused great physical or mental pain or suffering to, or serious injury to body or health of, one or more persons.

2. Such person or persons were protected under one or more of the Geneva Conventions of 1949.

3. The perpetrator was aware of the factual circumstances that established that protected status.

4. The conduct took place in the context of and was associated with an international armed conflict.

5. The perpetrator was aware of factual circumstances that established the existence of an armed conflict. ${ }^{42}$

According to Article 128 of the UCMJ aggravated assault occurs in the following circumstances:

1. That the accused attempted to do, offered to do, or did bodily harm to a certain person;

2. That the accused did so with a certain weapon, means, or force;

3. That the attempt, offer, or bodily harm was done with unlawful force or violence; and

4. That the weapon, means, or force was used in a manner likely to produce death or grievous bodily harm. ${ }^{43}$

There are a number of subsets of this offence, including when a firearm is used and when it is committed against a child under the age of sixteen years. Absent one of those qualifiers, the maximum punishment is a dishonourable discharge, forfeiture of all pay and allowances, and confinement for three years.

Of the offences being compared, these two (wilfully causing great suffering and aggravated assault) may be the most similar. Interestingly the UCMJ version applies to attempts and completed acts, while the ICC offence only applies to the completed acts. The ICC offence encompasses mental pain or suffering while the UCMJ version is limited to bodily harm. Again disparity between the possible punishments arises: the ICC crime yields a sentence range up to thirty years while the UCMJ is generally limited to three years. Even when the qualifiers are considered, the UCMJ

42 Ibid., art. 8(2)(a)(iii).

${ }^{43}$ Uniform Code of Military Justice, 10 USC $\$ 928$ art. 128 (2010). 
punishment only increases to five years for a child victim and eight years when a firearm is used.

\section{$D$ Destruction of property}

The crime of extensive destruction and appropriation of property is defined in the Rome Statute as occurring when:

1. The perpetrator destroyed or appropriated certain property.

2. The destruction or appropriation was not justified by military necessity.

3. The destruction or appropriation was extensive and carried out wantonly.

4. Such property was protected under one or more of the Geneva Conventions of 1949.

5. The perpetrator was aware of the factual circumstances that established that protected status.

6. The conduct took place in the context of and was associated with an international armed conflict.

7. The perpetrator was aware of factual circumstances that established the existence of an armed conflict. ${ }^{44}$

Article 103 of the UCMJ provides that the crime of looting or pillaging captured or abandoned property occurs in the following circumstances:

1. That the accused engaged in looting, pillaging, or looting and pillaging by unlawfully seizing or appropriating certain public or private property.

2. That this property was located in enemy or occupied territory, or that it was on board a seized or captured vessel.

3. That this property was

(i) left behind, owned by, or in the custody of the enemy, an occupied state, an inhabitant of an occupied state, or a person under the protection of the enemy or occupied state, or who, immediately prior to the occupation of the place where the act occurred, was under the protection of the enemy or occupied state; or

(ii) part of the equipment of a seized or captured vessel; or

${ }^{44}$ Rome Statute, above n. 34, art. 8(2)(a)(iv). 
(iii) owned by, or in the custody of the officers, crew, or passengers on board a seized or captured vessel. ${ }^{45}$

The maximum punishment is 'any punishment, other than death, that a court-martial may direct'. ${ }^{46}$

The striking feature of the UCMJ charge is that it represents a rare US military offence - one that only applies to armed conflict or during times of military occupation. Although anachronistic, this offence nonetheless demonstrates the potential for broader offences unique to armed conflict to apply to US service members.

\section{Conclusion}

The above discussion demonstrates that in some ways the crimes in the UCMJ and the Rome Statute are analogous, but in other ways they are not. The enumerated UCMJ offences are more generalised, allowing for application both during peacetime garrison settings and during armed conflict. But in that generalisation, it can be claimed that something is lost. Is the same offence in a garrison setting really the same as when it is committed in an armed conflict? For intra-military offences, for example one service member assaulting another, the answer may be yes. But where the victim of the offence is not American and the armed forces are deployed in an armed conflict environment the answer would appear to be negative. The question becomes whether the various intrinsic and extrinsic values of the US military justice system - designed to promote, protect, and defend - operate in a domestic setting in the same manner as they do in an armed conflict.

One senior US military prosecutor has commented that charging decisions ultimately reflect the narrative the prosecutor wants to convey to a jury. It is difficult to envision a case where adding elements, including the existence of armed conflict or of a protected person, would render that endeavour easier. A pragmatic approach to prosecutions is not unique to the United States. ${ }^{47}$ The differences may be explained by degrees - a domestic military charge would apply to a lower ranking

${ }^{45}$ Uniform Code of Military Justice, 10 USC $\$ 903$ art. 103 (2010). ${ }^{46}$ Ibid.

47 Interview with Beth Van Schaack, Deputy Chief of the US Office of Global Criminal Justice describing actions by ICTY prosecutors to employ charges that obviate the need for conflict classification and the use of joint criminal enterprise as a more effective modality than traditional forms of command responsibility. 
individual, whereas a 'war criminal' must be an authority figure. Or, it could be argued that property destruction is appropriately addressed by the UCMJ, and that a war crime act of the same conduct would, or should, constitute a graver crime.

Yet the US approach rings hollow, maybe not in an absolute sense but certainly in a relative one. The United States has been involved in armed conflict for over ten years and claims to be in an era of 'persistent conflict $^{48}$ which it believes will exist for 'the next several decades'. ${ }^{49}$ This negates an argument that armed conflicts are not long enough to warrant unique military charges. ${ }^{50}$ Nor is the argument that specific offences should only exist when they occur with some degree of frequency particularly persuasive given the presence in the UCMJ of offences such as abusing a public animal and hazarding a vessel. But fatally problematic for the US pragmatism argument is that law of war offences are detailed and employed against detainees subject to US military commissions. ${ }^{51}$ For either reason, and certainly for both reasons, the United States should modify the charges employed against its own service members.

${ }^{48}$ Pete Geren and George W. Casey Jr, A Statement on the Posture of the United States Army 2009 Submitted by The Honorable Pete Geren and General George W Casey JR to the Committees and Subcommittees of the United States Senate and the House of Representatives 1st Session, 111th Congress (Washington, DC, May 2009) (introduction).

49 See also Mary L. Dudziak, War Time: An Idea, Its History, Its Consequences (Oxford, Oxford University Press, 2012) arguing that war is not an exceptional state but the unfortunate status quo.

50 Moreover, as discussed above, the US military manual for courts martial has for some time contained a few conflict specific offences.

51 This inconsistent approach to the way in which the United States charges its service members versus the enemy is not new. During World War II, the US Army courtmartialled its own service members for killing enemy prisoners of war for murder, while prosecuting Germans who committed similar acts against US POWs for violations of the laws and customs of war. See US011 Case No. 6-24 (US v. Valentin Bersin et al.). 